\title{
Microbacterium kitamiense sp. nov., a new polysaccharide-producing bacterium isolated from the wastewater of a sugar-beet factory
}

\author{
Hidetoshi Matsuyama, ${ }^{1}$ Kosei Kawasaki, ${ }^{2}$ Isao Yumoto ${ }^{2}$ \\ and Osamu Shida ${ }^{3}$ \\ Author for correspondence: Hidetoshi Matsuyama. Tel: +81 11 5715111. Fax: +81 115717879.
e-mail: matsuyama@db.htokai.ac.jp
}

Department of Bioscience and Technology, School of Engineering, Hokkaido Tokai University, Minamisawa, Minami-ku, Sapporo 005-8601, Japan

2 Bioscience and Chemistry Division, Hokkaido National Industrial Research Institute, Tsukisamu-Higashi, Toyohira-ku, Sapporo 062-8517, Japan

3 Research Laboratory, Higeta Shoyu Co., Ltd, Choshi, Chiba 288-8680, Japan

\begin{abstract}
Two strictly aerobic, heterotrophic and mesophilic new organisms, strains Kitami A1 and Kitami C2 ${ }^{\top}$, were isolated from the wastewater of a sugar-beet factory in Kitami City, Hokkaido, Japan. In batch cultures, these organisms produced both insoluble and soluble exopolysaccharides (EPSs) utilizing sucrose as the sole carbon source. The $\mathrm{G}+\mathrm{C}$ contents of the strains Kitami C2 ${ }^{\mathrm{T}}$ and Kitami A1 were $69.2 \mathrm{~mol} \%$. Both strains had anteiso-C15:0 acid, anteisoC17:0 acid and iso-C16:0 as major components. The major isoprenoid quinones from these strains included menaquinone-11 and menaquinone-12.

Physiological and biochemical characterization, phylogenetic analysis and DNA-DNA relatedness indicated that these two organisms are new species of the genus Microbacterium, for which the name Microbacterium kitamiense is proposed. The type strain of $M$. kitamiense is strain Kitami $\mathrm{C2}^{\top}$ ( = JCM 10270').
\end{abstract}

Keywords: Microbacterium kitamiense, polysaccharide, industrial wastewater

\section{INTRODUCTION}

There have been many reports on micro-organisms that produce exopolysaccharides (EPSs). Some of the bacterial polysaccharides are produced on an industrial scale and are used as raw materials in food processing and in medical and industrial preparations. It remains possible that new polysaccharide-producing bacteria could be found in various habitats. Recently, new polysaccharide-producing bacteria were isolated from a deep-sea hydrothermal vent (Raguenes et al., 1996, 1997a, b).

We tried to find new polysaccharide-producing bacteria from wastewater obtained from several factories; we isolated numerous bacteria that produced polysaccharide in our laboratory. The strains Kitami $\mathrm{C}^{\mathrm{T}}$ and Kitami Al were both isolated as polysaccharide producers from the wastewater of a sugar-beet factory in Kitami, Hokkaido, Japan.

In this study, we examined the physiological and

\section{Abbreviation: EPS, exopolysaccharide.}

The GenBank/EMBLDDBJ accession numbers for the 165 rRNA sequences reported in this paper are AB013907 (Kitami C2 $^{\top}$ ) and AB013920 (Kitami A1). biochemical features, the chemotaxonomic characteristics and the phylogeny of these strains. DNA-DNA relatedness data showed that the strains should be classified as a new species of the genus Microbacterium.

\section{METHODS}

Bacterial strains and cultivation. EPS-producing bacteria, Kitami $\mathrm{C}^{\mathrm{T}}$ and Kitami A1, were isolated from the wastewater of a sugar-beet factory in Kitami City, Japan. The organisms were cultivated aerobically at $25^{\circ} \mathrm{C}$ in tryptic soy agar (Difco), unless otherwise stated.

Production of EPS. A basal culture medium ( $\mathrm{pH} 8.5$ ) for EPS production contained $1.5 \%(\mathrm{w} / \mathrm{v})$ sucrose, $0.075 \% \mathrm{CaCO}_{3}$, $0.05 \% \mathrm{MgSO}_{4}, 0.1 \% \mathrm{~K}_{2} \mathrm{HPO}_{4}, 0.0001 \% \mathrm{Na}_{2} \mathrm{MoO}_{4}, 0.01 \%$ $\mathrm{KNO}_{3}$ and $1 \%$ trace-element solution (Patel, 1984). For the production of EPS, the bacteria were cultured at $25^{\circ} \mathrm{C}$ for $7 \mathrm{~d}$ in a $500 \mathrm{ml}$ Erlenmeyer flask containing $100 \mathrm{ml}$ of the above medium by rotary shaking with $10 \mathrm{ml}$ seed culture.

Isolation of EPS from culture fluid. For preparation of the EPS fraction, the culture broth from the Erlenmeyer flask was centrifuged at $11000 \mathrm{~g}$ for $10 \mathrm{~min}$ to remove bacterial cells. The supernatant was again centrifuged at $14000 \mathrm{~g}$ for $30 \mathrm{~min}$. A clear supernatant and a gelatinous matrix were recovered. To the supernatant fraction, three volumes of ethanol were added and the precipitate was collected by centrifugation at $10000 \mathrm{~g}$ for $10 \mathrm{~min}$. The precipitate was 
dissolved in distilled water and dialysed overnight against the distilled water; this was followed by lyophilization. The polymer obtained was designated 'soluble EPS'. The gelatinous matrix fraction was suspended and dialysed overnight against distilled water and then lyophilized. The polymer obtained was designated 'insoluble EPS'. The weights of the lyophilized EPSs were measured gravimetrically.

Chemical analysis of EPS. The total carbohydrate content was determined using the phenol/sulfuric acid method (Dubois et al., 1956). The protein content was determined according to the method of Lowry et al. (1951), with bovine serum albumin as a standard. EPS constituents were examined as their alditol acetate by GLC; this was followed by hydrolysis of the EPS. GLC analysis was performed on a Hitachi chromatograph model G-3000 equipped with a flame-ionization detector: a capillary column sp-2330 $(0.25 \mathrm{~mm} \times 40 \mathrm{~m}$; Supelco $)$ was used. For GLC analysis, the derivative procedure used was that of Albersheim et al. (1967). The uronic acid was analysed qualitatively by the method of Thomas \& Albersheim (1972).

Physiological and biochemical characterization. The physiological and biochemical characterization of the two strains isolated was determined as described by Komagata (1985).

Cell wall analysis. Cell wall analysis was performed as described by Schleifer \& Kandler (1972). The glycolate test was performed according to the method of Uchida \& Aida (1977).

Quinone composition. Cells cultivated overnight in tryptic soy broth at $25^{\circ} \mathrm{C}$ were used to determine the quinone composition, as described by Komagata \& Suzuki (1987).

Cellular fatty acid composition. Cells cultivated overnight in tryptic soy broth at $25^{\circ} \mathrm{C}$ were used for cellular fatty acid analysis according to the method described by Suzuki \& Komagata (1983).

DNA base composition and DNA-DNA hybridization. Chromosomal DNA was prepared from bacterial cells according to the method of Marmur (1961). The G+C content of DNA was determined according to the method of Tamaoka \& Komagata (1984).

Levels of DNA relatedness were determined by the method of Ezaki et al. (1989). Probes for DNA-DNA hybridization were prepared from Kitami $\mathrm{C}_{2}{ }^{\mathrm{T}}$, Kitami $\mathrm{A} 1$ and type strains of Microbacterium aurantiacum IFO $15234^{\mathrm{T}}$ and Microbacterium chocolatum IFO $3758^{\mathrm{T}}$

Determining and comparing 16S rRNA gene sequences. Cloning and sequencing of 16S rRNA genes were carried out by the method described previously (Shida et al., 1997). The phylogenetic tree was created by the neighbour-joining method (Saito \& Nei, 1987), using $K_{\text {nuc }}$ values (Kimura, 1980 ). The topology of the tree was evaluated by performing a bootstrap analysis using the CLUSTAL w version 1.5 program (Thompson et al., 1994).

\section{RESULTS AND DISCUSSION}

\section{Production and characterization of the EPS}

In batch cultures in the presence of sucrose (Erlenmeyer flasks at $25^{\circ} \mathrm{C}$ for $7 \mathrm{~d}$ ), these organisms produced both insoluble and soluble EPSs. The yields
Table 1. Characteristics of strains Kitami $C 2^{\top}$ and Kitami A1

NC, No change; + , positive; - , negative. Both strains were negative for the oxidase test, and for hydrolysis of casein, urea, Tweens 20, 40,60 and 80, and for utilization of citrate, succinate, fumarate, propionate, and for formation of indole and production of hydrogen sulfide, and acid production from inositol, sorbose, lactose, ribose, salicin, sorbitol, melibiose and adonitol, and for gas production from glucose, arabinose, xylose and mannitol, and for growth in $0.02 \%$ $\mathrm{NaN}_{3}$ or $0.01 \%$ lysozyme. Both strains were positive for catalase, hydrolysis of gelatin, starch, DNA, and for decompostion of tyrosine, and for utilization of ammonium and nitrate, and for acid production from glucose, fructose, galactose, mannose, maltose, arabinose, sucrose, xylose, trehalose, glycerol, mannitol and raffinose, and for growth in 2,5 or $7 \% \mathrm{NaCl}$.

\begin{tabular}{|lcc|}
\hline Characteristic & Kitami C2 & Kitami A1 \\
\hline Litmus milk & $\mathrm{NC}$ & $\mathrm{NC}$ \\
Nitrate reduction & - & + \\
Voges-Proskauer & - & - \\
pH in Voges-Proskauer & $5 \cdot 2$ & $5 \cdot 3$ \\
pH range & $6 \cdot 0-9 \cdot 0$ & $6 \cdot 0-9 \cdot 0$ \\
Temperature range $\left({ }^{\circ} \mathrm{C}\right)$ & $15-37$ & $15-37$ \\
Acid production from: & & \\
$\quad$ Cellobiose & - & + \\
Rhamnose & - & + \\
\hline
\end{tabular}

of soluble and insoluble EPSs of Kitami $\mathrm{C}^{\mathrm{T}}$ were about $0.5 \mathrm{~g} \mathrm{l}^{-1}$ and $1.8 \mathrm{~g} \mathrm{l}^{-1}$, respectively; yields of soluble and insoluble EPSs of Kitami A1 were $0.8 \mathrm{~g} \mathrm{l}^{-1}$ and $5.0 \mathrm{~g} \mathrm{l}^{-1}$, respectively. These EPS contained trace amounts of protein and no uronic acid. The sugar constituents of soluble EPSs of Kitami C2 ${ }^{\mathrm{T}}$ were $14 \%$ $(\mathrm{w} / \mathrm{w})$ rhamnose, $19 \%$ mannose, $25 \%$ galactose and $42 \%$ glucose, while those of insoluble EPSs were $27 \%$ rhamnose, $13 \%$ mannose, $9 \%$ galactose and $51 \%$ glucose. The sugar constituents of the soluble EPS of Kitami Alwere $31 \%$ rhamnose, $19 \%$ mannose and $50 \%$ glucose, while those of insoluble EPS were $25 \%$ rhamnose, $11 \%$ mannose, $21 \%$ galactose and $43 \%$ glucose. These data suggested that the sugar constituents of Kitami $\mathrm{C} 2^{\mathrm{T}}$ bear a close resemblance to those of Kitami A1.

\section{Morphological, physiological and biochemical characterization}

Strains Kitami $\mathrm{C}^{\mathrm{T}}$ and Kitami $\mathrm{A} 1$ were strictly aerobic, non-motile, non-sporing, Gram-positive irregular rods $(0.5-0.8 \times 1.0-2.0 \mu \mathrm{m})$. After $5 \mathrm{~d}$ growth at $25^{\circ} \mathrm{C}$, colonies on tryptic soy agar were circular, round, capitate, smooth, orange in colour, glistening and about $1.5-3.0 \mathrm{~mm}$ in diameter. The physiological and biochemical characteristics of these strains are shown in Table 1. 


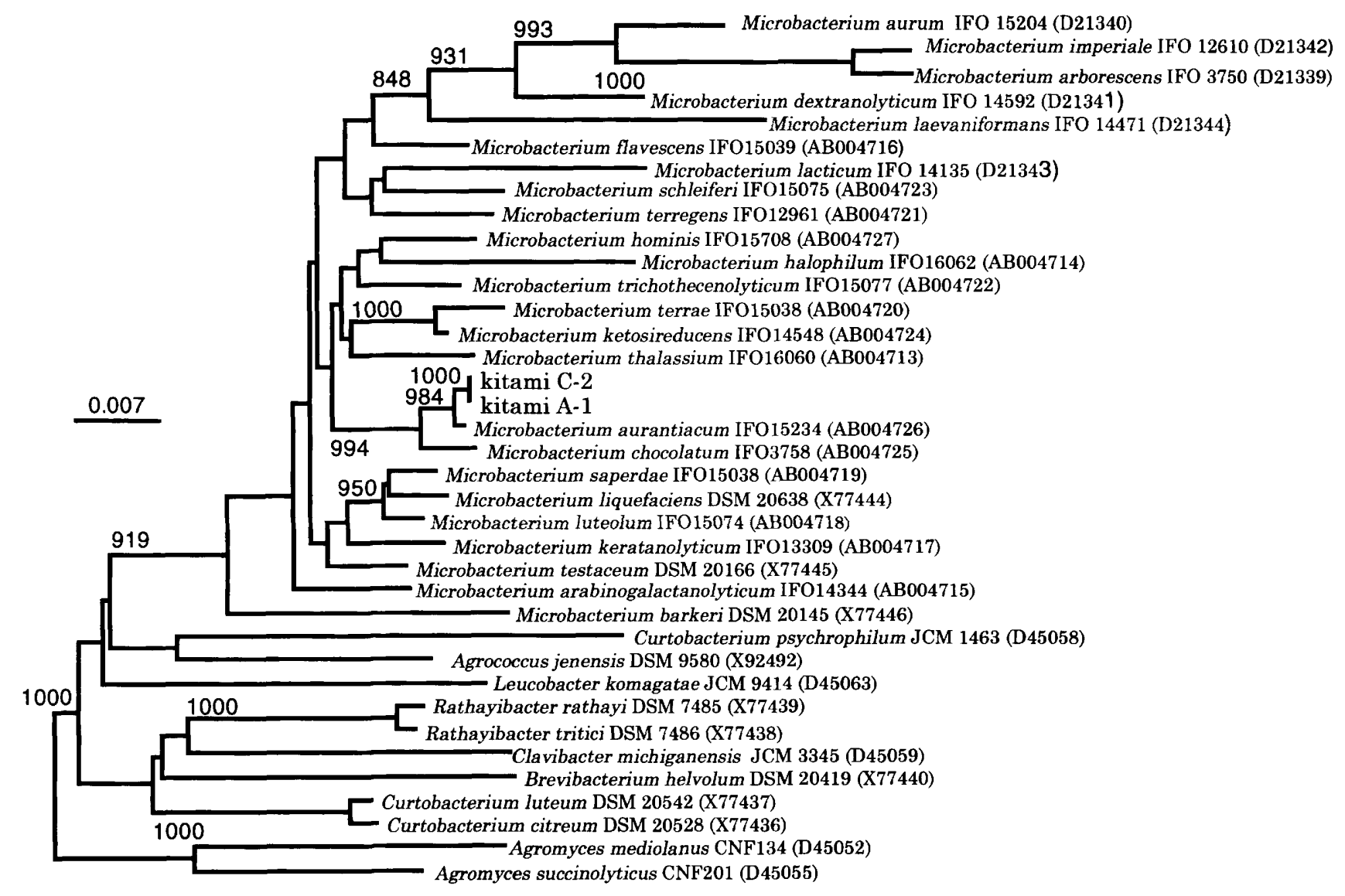

Fig. 1. Phylogenetic tree derived from $16 \mathrm{~S}$ rRNA sequence data for strain Kitami $C 2^{\top}$, strain Kitami $A 1$ and other species. Bar, $0.007 K_{\text {nuc }}$ units.

\section{Chemotaxomic characteristics}

The cell wall peptidoglycan of strains Kitami $\mathrm{C}^{\mathrm{T}}$ and Kitami A1 contained D-ornithine, as diamino acid, and the glycan moiety of the cell wall contained glycolate residues.

The major isoprenoid quinones from these strains contained menaquinone 11 (MK-11, 67-68\% of total quinones) and menaquinone 12 (MK-12, 18-24\% of total quinones).

In strains Kitami $\mathrm{C}^{\mathrm{T}}$ and Kitami $\mathrm{A} 1$, anteiso-C15:0 acid ( $40-47 \%$ of total cellular fatty acids), anteiso$\mathrm{C} 17: 0$ acid (32-39\%) and iso-C16:0 acid (10-13\%) were major components.

\section{Phylogenetic analysis}

The 16S rRNA gene-similarity value for Kitami $\mathrm{C}^{\mathrm{T}}$ and Kitami Al was $100 \%$. The sequence-similarity values $(>94 \%)$ placed these strains within the realm of the genus Microbacterium. A phylogenetic tree of strains Kitami $\mathrm{C}^{\mathrm{T}}$ and Kitami $\mathrm{A} 1$, based on $16 \mathrm{~S}$ rRNA gene sequences, is shown in Fig. 1. These two strains were members of a robust, monophyletic cluster containing the Microbacterium species (Fig. 1). Re- cently, the genus Microbacterium was emended; additional species have been described by Takeuchi $\&$ Hatano (1998a, b).

\section{DNA base composition and DNA relatedness}

The $\mathrm{G}+\mathrm{C}$ content of strains Kitami $\mathrm{C}^{\mathrm{T}}$ and Kitami Al was $69 \cdot 2 \mathrm{~mol} \%$ (Table 2). The two isolates were located on the same branch as $M$. aurantiacum and $M$. chocolatum under the high bootstrap value in the phylogenetic tree based on 16S rRNA sequences (Fig. 1). Therefore, we estimated the DNA-DNA relatedness value by using strains $M$. aurantiacum and $M$. chocolatum as the references. DNA relatedness values for Kitami $\mathrm{C}^{\mathrm{T}}$ and Kitami A1 were $100 \%$ (Table 2). The values for relatedness to $M$. aurantiacum and $M$. chocolatum (60-69\%) were not high enough to permit identification as the same species (Table 2).

Differential characteristics of Kitami $\mathrm{C}^{\mathrm{T}}$ and the 26 previously described species of the genus Microbacterium are summarized in Table 3 . According to the phylogenetic analysis based on the 16S rRNA sequence and DNA-DNA relatedness data, the isolates were not very distant from $M$. aurantiacum and $M$. chocolatum. However, on the basis of the physio- 
Table 2. DNA base compositions and levels of DNA relatedness

\begin{tabular}{|lcccc|}
\hline Strain* & $\begin{array}{c}\text { G+C content } \\
\text { (mol \%) }\end{array}$ & \multicolumn{3}{c|}{ Reassociation (\%) with DNA from: $\dagger$} \\
\cline { 3 - 4 } & & $\begin{array}{c}\text { M. chocolatum } \\
\text { IFO 3758 }^{\mathbf{T}}\end{array}$ & $\begin{array}{c}\text { M. aurantiacum } \\
\text { IFO 15234 }^{\mathbf{T}}\end{array}$ & $\begin{array}{c}\text { Kitami } \\
\text { C2 }^{\mathbf{T}}\end{array}$ \\
\hline M. chocolatum IFO 3758 & $69 \cdot 2$ & 100 & 68 & 69 \\
M. aurantiacum IFO 15234 & & 65 & 100 & 67 \\
Kitami C2 & $69 \cdot 3$ & 60 & 68 & 100 \\
Kitami A1 & $69 \cdot 2$ & 63 & 68 & 100 \\
\hline
\end{tabular}

* IFO, Institute for Fermentation, Osaka, Japan.

$\dagger$ Reassociation values are means of two determinations; the maximum difference noted between two determinations was $9 \%$.

\section{Table 3. Differential characteristics of Microbacterium species}

Species: 1, M. kitamiense; 2, M. lacticum; 3, M. dextranolyticum; 4, M. imperiale; 5, M. arborescens; 6, M. aurum; 7, M. laevaniformans $; 8, M$. liquefaciens $; 9, M$. flavescens; $10, M$. terregens $; 11, M$. saperdae $; 12$, M. barkeri $; 13, M$. testaceum; 14, M. esteraromaticum; $15, M$. arabinogalactanolyticum; $16, M$. keratanolyticum $; 17, M$. terrae $; 18, M$. trichochecenolyticum; $19, M$. luteolum; $20, M$. schleiferi $; 21$, M. aurantiacum $; 22, M$. chocolatum; 23, M. halophilum $; 24$, M. hominis; 25, M. ketosireducens; 26, M. maritypicum; $27, M$. thalassium. Y, yellow; W/Y, white or yellow; W, white; O, orange; w, weakly positive; d, different reactions; + , positive; - , negative.

\begin{tabular}{|c|c|c|c|c|c|c|c|c|c|c|c|c|c|c|c|c|c|c|c|c|c|c|c|c|c|c|c|}
\hline Characteristic & 1 & $2^{*}$ & $3^{*}$ & $4^{*}$ & $5^{*}$ & $6^{*}$ & $7 *$ & $8 \dagger$ & $9 \dagger$ & $10 \dagger$ & $11 \dagger$ & $12 \dagger$ & $13 \dagger$ & $14 \dagger$ & $15 \dagger$ & $16 \dagger$ & $17 \dagger$ & $18 \dagger$ & $19 \dagger$ & $20 \dagger$ & $21 \ddagger$ & $22+$ & $23 \ddagger$ & $24 \ddagger$ & $25 \ddagger$ & $26+$ & $27+$ \\
\hline Colour of colonies & $\mathrm{O}$ & $\mathrm{Y}$ & $\mathrm{Y}$ & $\mathrm{o}$ & $\mathrm{O}$ & $\mathrm{Y}$ & $\mathrm{Y}$ & $\mathrm{Y}$ & Y & $\mathrm{Y}$ & $\mathrm{W} / \mathrm{Y}$ & $\mathrm{Y}$ & 0 & $\mathrm{Y}$ & W & $\mathrm{Y}$ & $\mathrm{Y}$ & $\mathrm{Y}$ & $\mathrm{W} / \mathrm{Y}$ & $\mathrm{Y}$ & $\mathrm{O}$ & $\mathrm{O}$ & $\mathrm{Y}$ & $\mathrm{W} / \mathrm{Y}$ & $\mathrm{Y}$ & $\mathrm{Y}$ & $\mathrm{Y}$ \\
\hline Motility & - & - & - & + & + & - & - & - & - & - & + & + & + & + & - & + & - & - & - & - & - & - & - & - & - & + & - \\
\hline Growth at $37^{\circ} \mathrm{C}$ & + & - & - & + & - & - & + & - & - & - & - & + & - & $\mathrm{d}$ & - & - & - & - & - & w & + & + & + & + & - & + & - \\
\hline $\mathrm{H}_{2} \mathrm{~S}$ formation & - & - & + & + & + & + & + & + & + & - & + & + & + & + & + & + & + & + & + & - & + & + & + & + & + & - & - \\
\hline Voges-Proskauer reaction & - & - & + & - & - & - & + & - & - & - & - & - & - & - & - & - & - & - & - & + & - & - & - & + & - & - & - \\
\hline \multicolumn{28}{|l|}{ Hydrolysis of : } \\
\hline Gelatin & + & - & - & - & + & + & + & + & + & - & - & + & + & - & + & + & + & - & - & - & - & - & $w$ & - & + & + & $\mathrm{w}$ \\
\hline Starch & + & + & - & + & - & + & + & - & + & - & + & + & - & + & + & - & + & + & - & - & + & + & + & - & + & - & + \\
\hline Tween 20 & - & - & + & - & - & - & - & - & + & - & + & + & + & $\mathrm{d}$ & - & - & $\mathrm{d}$ & + & - & d & + & + & $\mathrm{w}$ & + & + & + & $\mathrm{w}$ \\
\hline Tween 40 & - & - & + & - & - & - & - & - & + & - & + & + & + & + & - & - & + & + & - & + & + & + & + & + & + & + & + \\
\hline Tween 60 & - & - & + & - & - & $\mathrm{w}$ & - & - & + & - & + & + & + & + & + & - & + & + & - & d & + & + & + & + & + & + & + \\
\hline Tween 80 & - & - & + & - & - & - & - & - & + & - & + & - & + & + & + & - & + & + & - & d & + & + & + & + & + & + & + \\
\hline \multicolumn{28}{|l|}{ Assimilation of: } \\
\hline Malate & - & + & - & + & - & - & + & + & - & + & + & + & + & + & + & + & $w$ & + & + & - & d & $\mathrm{d}$ & - & + & $\mathrm{d}$ & + & - \\
\hline Fumarate & - & + & + & + & + & - & + & + & w & + & + & + & + & + & + & + & + & + & + & - & + & $\mathrm{d}$ & - & + & $\mathrm{d}$ & - & - \\
\hline Propionate & - & + & - & - & - & -- & + & + & w & + & + & w & $\mathrm{w}$ & + & + & + & $\mathrm{d}$ & $\mathrm{w}$ & + & - & + & $d$ & - & + & d & - & - \\
\hline
\end{tabular}

* Data from the description by Yokota et al. (1993a).

$\dagger$ Data from the description by Yokota et al. (1993b).

\$Data from the description by Takeuchi \& Hatano (1998b).

logical and biochemical characteristics, the isolates were obviously different from these two strains. These characteristics in Table 3 also indicated that strain Kitami $C 2^{\mathrm{T}}$ can be distinguished easily from all previously described species of the genus Microbacterium. In our opinion, this strain warrants the status of a new taxon; therefore, we propose that strains Kitami C2 $2^{\mathrm{T}}$ and Kitami A1 should be classified as new species in the genus Microbacterium, namely Microbacterium kitamiense sp. nov.

\section{Description of Microbacterium kitamiense sp. nov.}

Microbacterium kitamiense (kita'mi.ense. M.L. adj. kitamiense referring to Kitami, a city in Hokkaido, Japan, where the organism was isolated).
The cells are irregular rods $(0.5-0.8 \mu \mathrm{m}$ in width, $1 \cdot 0-2 \cdot 0 \mu \mathrm{m}$ in length). Gram-positive, non-motile and non-sporing. Strictly aerobic, catalase-positive and oxidase-negative. The $\mathrm{pH}$ in Voges-Proskauer broth is 5.7. Hydrogen sulfide and indole are not produced. Gelatin and starch are hydrolysed. Casein, DNA, Tweens 20, 40, 60 and 80 and urea are not hydrolysed. Tyrosine is decomposed. Citrate, propionate, fumarate, L-malate and succinate are not utilized. Nitrate and ammonium are utilized. Growth occurs at temperatures between 15 and $37^{\circ} \mathrm{C}$ and at $\mathrm{pH} 6 \cdot 0-9 \cdot 0$. Growth occurs in the presence of $7 \% \mathrm{NaCl}$. Growth is inhibited by $0.02 \% \mathrm{NaN}_{3}$ and by $0.01 \%$ lysozyme. Acid, but no gas, is produced from glucose, arabinose, xylose and mannitol. The cell wall peptidoglycan contains D-ornithine as diamino acid and there are 
high levels of glycolate in the glycan moiety of the cell wall. The major fatty acids are anteiso-C15:0, anteiso$\mathrm{C} 17: 0$ and iso-C16:0. The major quinones are menaquinone 11 and menaquinone 12 . The $\mathrm{G}+\mathrm{C}$ content of type strain is $69 \cdot 2 \mathrm{~mol} \%$. The type strain, Kitami $\mathrm{C2}^{\mathrm{T}}$, has been deposited at the Institute of Physical and Chemical Research, Wako, Japan, as strain JCM $10270^{\mathrm{T}}$.

\section{ACKNOWLEDGEMENTS}

We thank Tasuku Nakajima, Department of Applied Biological Chemistry, Tohoku University, for discussions. This study was supported by Special Coordination Funds for Promoting Science and Technology (Science and Technology Agency of the Japanese Government).

\section{REFERENCES}

Albersheim, P., Nevins, D. J., English, P. D. \& Karr, A. (1967). A method for the analysis of sugars in plant cell-wall polysaccharides by gas-chromatography. Carbohydr Res 5, 340-345.

Dubois, M., Gilles, K. A., Hamilton, J. K., Rebers, P. A. \& Smith, F. (1956). Calorimetric method for determination of sugars and related substances. Anal Chem 28, 350-356.

Ezaki, T., Hashimoto, Y. \& Yabuuchi, E. (1989). Fluorometric dcoxyribonucleic acid-deoxyribonucleic acid hybridization in microdilution wells as an alternative to membrane filter hybridization in which radioisotopes are used to determine genetic relatedness among bacterial strains. Int J Syst Bacteriol 39, 224-229.

Kimura, M. (1980). A simple method for estimating evolutionary rates of base substitutions through comparative studies of nucleotide sequences. $J$ Mol Evol 16, 111-120.

Komagata, K. (1985). Bacteria (1): the aerobic bacteria. In Classification and Identification of Microorganisms, vol. 2, pp. 99-161. Edited by T. Hasegawa: Tokyo: Gakkai Schuppan (in Japanese).

Komagata, K. \& Suzuki, K. (1987). Lipid and cell-wall analysis in bacterial systematics. Methods Microbiol 19, 161-207.

Lowry, O. H., Rosebrough, N. J., Farr, A. L. \& Randall, R. J. (1951). Protein measurement with the Folin phenol reagent. $J$ Biol Chem 193, 265-275.

Marmur, J. (1961). A procedure for the isolation of deoxyribonucleic acid from micro-organisms. J Mol Biol 3, 208-218.

Patel, G. B. (1984). Characterization and nutritional properties of Methanothrix concilii sp. nov., a mesophilic acetoclastic methanogen. Can J Microbiol 30, 1383-1396.

Raguenes, G., Pignet, P., Gauthier, G., Peres, A., Christen, R., Rougeaux, H., Barbier, G. \& Guezennec, J. (1996). Description of a new polymer-secreting bacterium from a deep-sea hydrothermal vent, Altermonas macleodii subsp. fijiensis, and preliminary characterization of the polymer. Appl Environ Microbiol 62, 67-73.

Raguenes, G., Christen, R., Guezennec, J., Pignet, P. \& Barbier, G. (1997a). Vibrio diabolicus sp. nov., a new polysaccharide secreting organism isolated from a deep-sea hydrothermal vent polychaete annelid, Alvinella pompejana. Int J Syst Bacteriol 47, 989-995.

Raguenes, G. H. C., Peres, A., Ruimy, R., Pignet, P., Christen, R., Loaec, M., Rougeaux, H., Barbier, G. \& Guezennec, J. G. (1997b). Alteromonas infernus sp. nov., a new polysaccharide-producing bacterium isolated from a deep-sea hydrothermal vent. $J A p p l$ Microbiol 82, 422-430.

Saito, N. \& Nei, M. (1987). A neighbor-joining method: a new method for reconstructing phylogenetic trees. Mol Biol Evol 4, 406-425.

Schleifer, K. H. \& Kandler, O. (1972). Peptidoglycan type of bacterial cell walls and their taxonomic implications. Bacteriol Rev 36, 407-477.

Shida, O., Takagi, H., Kadowaki, K., Nakamura, L. K. \& Komagata, K. (1997). Transfer of Bacillus alginolyticus, Bacillus chondroitinus, Bacillus curdlanolyticus, Bacillus glucanolyticus, Bacillus kobensis, and Bacillus thiaminolyticus to the genus Paenibacillus and emended description of the genus Paenibacillus. Int J Syst Bacteriol 47, 289-298.

Suzuki, K. \& Komagata, K. (1983). Taxonomic significance of cellular fatty acid composition in some coryneform bacteria. Int $J$ Syst Bacteriol 33, 188-200.

Takeuchi, M. \& Hatano, K. (1998a). Union of the genera Microbacterium Orla-Jensen and Aureobacterium Collins et al. in a redefined genus Microbacterium. Int $J$ Syst Bacteriol 48, 739-747.

Takeuchi, M. \& Hatano, K. (1998b). Proposal of six new species in the genus Microbacterium and transfer of Flavobacterium marinotypicum ZoBell and Upham to the genus Microbacterium as Microbacterium maritypicum comb. nov. Int $J$ Syst Bacteriol 48, 973-982.

Tamaoka, J. \& Komagata, K. (1984). Determination of base composition by reversed-phase high-performance liquid chromatography. FEMS Microbiol Lett 25, 125-128.

Thomas, M. J. \& Albersheim, P. (1972). A gas chromatographic method for the determination of aldose and uronic acid constituents of plant cell wall polysaccharides. Plant Physiol 49, 926-936.

Thompson, J. D., Higgins, D. G. \& Gibson, T. J. (1994). CLUSTAL $\mathrm{W}$ : improving the sensitivity of progressive multiple sequence alignment through sequence weighing, position-specific gap penalties and weight matrix choice. Nucleic Acids Res 22 , 4673-4680.

Uchida, K. \& Aida, K. (1977). Acyl type of bacterial cell wall: its simple identification by a colorimetric method. J Gen Appl Microbiol 23, 249-260.

Yokota, A., Takeuchi, M. \& Weiss, N. (1993a). Proposal of two new species in the genus Microbacterium: Microbacterium dextranolyticum sp. nov. and Microbacterium aurum sp. nov. Int $J$ Syst Bacteriol 43, 549-554.

Yokota, A., Takeuchi, M., Sakane, T. \& Weiss, N. (1993b). Proposal of six new species in the genus Aureobacterium and transfer of Flavobacterium esteraromaticum Omelianski to the genus Aureobacterium as Aureobacterium esteraromaticum comb. nov. Int J Syst Bacteriol 43, 555-564. 